\title{
Cerebral salt wasting syndrome in patients with minor head trauma - two case reports
}

\author{
Gabriela Csipak ${ }^{1}$, Natalia Hagau ${ }^{1,2}$
}

${ }^{1}$ Department of Anaesthesia and Intensive Care, Emergency County Hospital, Cluj-Napoca, Romania

2 "Iuliu Hațieganu" University of Medicine and Pharmacy, Cluj-Napoca, Romania

\begin{abstract}
We describe two polytrauma patients without severe head trauma who developed Cerebral Salt Wasting Syndrome (CSWS) during their stay in our ICU with natriuresis, hyponatremia and hypovolemia. Hyponatremia encountered in CSWS and the syndrome of inadequate antidiuretic hormone secretion (SIADH) is a common electrolyte finding in patients with severe head trauma, subarachnoid hemorrhage, malignancy and infections of the central nervous system. CSWS was an unexpected electrolyte finding in our patients with minor head trauma without neurological or neurosurgical problems.

To rule out other causes of hyponatremia (SIADH, secondary adrenal dysfunction and thyroid dysfunction) a correct diagnosis is very important, as proper treatment of CSWS with fluid and salt replacement will decrease mortality and morbidity.

In conclusion, CSWS should be suspected in any polytrauma patient with minor head trauma and hyponatremia.
\end{abstract}

Keywords: cerebral salt wasting syndrome, hypovolemic hyponatremia, head trauma

\section{Introduction}

Acute hyponatremia is the most common electrolyte finding in critically ill neurological patients [1]. It is important to know the etiology of hyponatremia because its treatment varies depending on its cause and inadequate treatment increases mortality and morbidity.

Cerebral salt wasting syndrome (CSWS) is characterized by the renal loss of sodium, leading to hyponatremia and hypovolemia. This syndrome occurs in patients with severe head trauma, malignancy, infections of central nervous system and subarachnoid hemorrhage

Adress for correspondence:

Dr. Gabriela Csipak

Spitalul Clinic Județean de Urgență str. Clinicilor 3-5

Cluj-Napoca, cod 400006, Romania

E-mail: gabi2001ro@hotmail.com after aneurismal rupture [2, 3]. It is important to ensure adequate sodium and volume balance in neurosurgical and neurotrauma patients in order to avoid the worsening of brain injury (secondary brain injury). Though described in severe head trauma, we found CSWS in two patients with minor head trauma, without oedema or other modifications at cerebral computed tomography (CT) scan, and without neurological symptoms.

\section{Case 1}

A male patient, aged 23, who suffered a car accident, was admitted in the intensive care unit (ICU) department of the Emergency County Hospital, ClujNapoca with the following diagnosis: minor head trauma without neurological or neurosurgical problems, no cerebral oedema at CT examination, facial trauma with comminuted fracture of the nasal bone and fracture of the internal wall of the maxillary sinus, thoracic trauma, pneumomediastinum, left clavicle 
fracture with displacement, multiple ribs fractures, pulmonary contusion, comminuted fracture of the left acetabulum with posterior dislocation of the femoral head, and comminuted fracture of the distal third of the left femur.

At admission, the patient was conscious, without retrograde amnesia (with a few minutes loss of consciousness during the accident) and with normal cerebral CT scan, hypothermic for a short period of time, hemodinamically stable and very anxious. Biologically, the patient showed acute anaemia, leukocytosis, rhabdomyolysis (serum creatinkinase 6612 $\mathrm{UI} / \mathrm{L}$ ), serum creatinine $1.24 \mathrm{mg} / \mathrm{dL}$.

During his ICU stay, the patient underwent three surgical interventions for the fixation of the inferior limbs fractures and for the fixation of the nasal bones. During this interval he developed a post traumatic stress disorder. Rhabdomyolysis lasted for 48 hours with the maximum value of creatinkinase $15642 \mathrm{UI} / \mathrm{L}$ and renal function was normal. In order to prevent acute renal failure induced by myoglobinuria, the patient was treated with fluids, osmotic and loop diuretics. He also received small doses (maximum $200 \mathrm{ml} / 24 \mathrm{~h}$ ) of sodium bicarbonate during the first five days of admission.

On the $10^{\text {th }}$ day after the accident, during his ICU stay, the patient developed polyuria (with a maximum urinary output of $12100 \mathrm{~mL} / 24$ hours), associated with thirst, dry mucosa, tachycardia, hypotension, decreased central venous pressure $\left(0 \mathrm{cmH}_{2} \mathrm{O}\right)$. Treatment consisted of volume replacement with saline solutions. Simultaneously, the patient developed hyponatremia and decreased serum osmolarity, with the lowest value on the $14^{\text {th }}$ day after admission, $254.8 \mathrm{mOsm} / \mathrm{L}$. Considering the patient's clinical findings and his biological status, more investigations were required to identify the underlying cause of hyponatremia and hypovolemia. At measured urinary electrolytes and important sodium and chloride wasting was found, maximal value during the $14^{\text {th }}$ day after admission $(1526 \mathrm{mmol} / 24 \mathrm{~h} \mathrm{Na}$ and $1654 \mathrm{mmol} / 24 \mathrm{~h} \mathrm{Cl}$ ). A complete hormonal assessment was performed with serum cortisol, TSH and serum $\mathrm{FT}_{4}$ levels within the normal range, indicating normal adrenal and thyroid function. The final diagnosis was CSWS, which remitted in 2-4 weeks. The electrolyte and water balance was followed up for two weeks after ICU discharge.

\section{Case 2}

A male patient, aged 19, suffered a car accident and was admitted initially for surveillance in another hospital, with the following diagnosis: minor head trauma (no loss of consciousness after the accident) without neurological or neurosurgical problems, pelvic fracture, femur fracture, tibial fracture.
During his initial ICU stay he developed sepsis, jaundice and abdominal pain. He was operated on and posttraumatic intestinal perforation was detected. He had an unfavorable postoperative course and after one week, he was transferred to our ICU with anastomotic fistula and sepsis. During his stay he underwent more than one surgery for anastomotic fistula.

At admission in our ICU the patient was conscious, tachypneic, tachycardic, with polyuria, hypovolemia, sweaty skin, no fever. He presented metabolic acidosis, leukocytosis, trombocytosis, hepatocytolisis, cholestasis, hyponatremia, hypokalemia, hypoalbuminemia, serum osmolarity $274 \mathrm{mOsm} / \mathrm{L}$. Because at admission, the patient was hypovolemic and polyuric, hyponatremia was initially attributed to an adrenal insufficiency secondary to sepsis. The measured serum cortisol within the normal range excluded a secondary adrenal insufficiency. TSH and $\mathrm{FT}_{4}$ levels lying within normal range demonstrated normal thyroid function. We found important urinary sodium and chloride wasting (768 $\mathrm{mmol} / 24 \mathrm{~h} \mathrm{Na}$ and $744 \mathrm{mmol} / 24 \mathrm{~h} \mathrm{Cl}$ ). Considering the clinical and laboratory findings, we excluded SIADH and the final diagnosis was CSWS.

\section{Discussion}

Acute or chronic hyponatremia is one of the most frequent disorders of body fluid and electrolyte imbalance encountered in clinical practice [4, 5]. Hyponatremia can be hypo-, iso- or hypertonic, hypo-, euor hypervolemic. The renal system, by handling sodium excretion and reabsorption, is crucial for the regulation of the adequacy of the effective circulating blood volume [6].

Chronic hypovolemic hyponatremia with urinary sodium $>20 \mathrm{mmol} / \mathrm{L}$ may be caused by diuretic use (thiazide diuretics), mineralocorticoid deficiency, and salt wasting nephropathy (family history). Other causes of chronic hyponatremia are: liver disease, congestive heart failure, hypothyroidism, and possibly ligands for the calcium receptor in the Henle loop (hypercalcemia, cationic drugs or cationic proteins) [7]. In our patients we excluded all causes of chronic hypovolemic hyponatremia and we ruled out the diagnosis of acute hyponatremia from secondary hypoaldosteronism because of the normal hormonal status of our patients.

Acute hyponatremia may have several causes in critically neurological patients: severe head injury, intracranial surgery, subarachnoid hemorrhage, brain infection and tumor.

In our patients we made differential diagnoses between SIADH and CSWS. The extracellular volume status made the difference between the two entities. SIADH presents with euvolemia or hypervolemic hyponatremia, without polyuria, while CSWS presents 
with hypovolemic hyponatremia caused by natriuresis and polyuria [8].

The differential diagnoses between these entities face many difficulties and pitfalls, but it is important because the treatment is very different, and inappropriate patient management may lead to devastating consequences $[9,10]$. In SIADH, the treatment consists of free water restriction, while for CSWS the treatment is the volume and salt loss replacement, and fluid restriction would likely be detrimental to neurological recovery [11]. Fludrocortisone is an optional treatment and carries the risk of side effects such as hypokalemia, pulmonary oedema and hypertension [12]. Thus, its use should be restricted to those patients where salt and fluid management cannot be handled in such a way that the excess of nastriuresis is counteracted [12-14].

The cause of hyponatremia in CSWS is not well understood. There seems to be an increase in natriuretic peptides that diminishes the activity of reninangiotensine-aldosteron axis [9]. Even though this system may play a role, in many case reports, the brain or atrial natriuretic peptides were low, normal or high [13].

Our patients with CSWS were hypovolemic, polyuric, hyponatremic, with a large urinary loss of natrium and chloride, but had a good response to volume and natrium replacement, the adequate response to this therapy, confirming CSWS.

CSWS is a diagnosis of exclusion that requires a hyponatremia and natriuresis in a patient with a contracted effective arterial blood volume in the absence of another cause for natriuresis [13]. There are conflicting data regarding hyponatremia correlation and the incidence of CSWS to the injury severity. In a prospective study on hyponatemia in patients with traumatic brain injury, hyponatremia did not correlate to the Glasgow Coma Scale after the traumatic event, but rather with the severity of brain injury as assessed by CT [15]. On the contrary, Leonard et al. found that the incidence of CSWS after traumatic brain injury was highest in patients with a Glasgow Coma Scale less than nine points [13]. Nonetheless, these studies excluded patients with mild head injuries and normal CT scans.

CSWS was an unexpected electrolyte finding in our patients with minor head trauma without neurological or neurosurgical lesions. The correct diagnosis imposed adequate treatment with replacement of the fluid and salt losses for 15 days in the first patient and for 26 days in the second patient.

In conclusion, CSWS should be considered in any polytrauma patient with minor head trauma and hyponatremia, because it is not specific only for seriously brain injured patients. In addition, physicians treating patients with neurological intracranial disease should include CSWS in the differential diagnosis for every case of hyponatremia.

\section{Conflict of interest}

Nothing to declare

\section{References}

1. Tisdall M, Crocker M, Watkiss J, Smith M. Disturbances of sodium in critically ill adult neurological patients: a clinical review. J Neurosurg Anaesthesiol 2006; 18: 57-63

2. Harrigan MR. Cerebral salt wasting syndrome. Crit Care Clin 2001; 17: 125-138

3. Cerdà-Esteve M, Cuadrado-Godia E, Chillaron JJ, Pont-Sunyer C, Cucurella G, Fernández $\mathrm{M}$, et al. Cerebral salt wasting syndrome: review. Eur J Intern Med 2008; 19: 249-254. DOI: 10.1016/j.ejim.2007.06.019

4. Spasovski G, Vanholder R, Allolio B, Annane D, Ball S, Bichet D, et al. Clinical practice guideline on diagnosis and treatment of hyponatraemia. Eur J Endocrinol 2014; 170: G1-G47. DOI: 10.1530/EJE-13-1020

5. Butcher BW, Liu KD. Hyponatremia and hypernatremia. In: Parsons PE, Wiener-Kronish JP, eds. Critical care secrets. $5^{\text {th }}$ edition. St. Louis: Elsevier/Mosby; 2013: 322-327

6. Caironi P, Langer T, Ferrari M. Urinary electrolyte monitoring in the critically ill: revisiting renal physiology. In: Vincent JL, editor. Annual update in intensive care and emergency medicine 2015. Berlin: Springer; 2015: 353-356, 361-362. DOI: $10.1007 /$ 978-3-319-13761-2

7. Singh S, Bohn D, Carlotti AP, Cusimano M, Rutka JT, Halperin ML. Cerebral salt wasting: truths, fallacies, theories, and challenges. Crit Care Med 2002; 30: 2575-2579. DOI: 10.1097/ 01.CCM.0000034676.11528.E4

8. Teig M, Smith M. Systemic complications of neurological disease. In: Matta BF, Menon DK, Smith M, eds. Core topics in neuroanaesthesia and neurointensive care. Cambridge: Cambridge University Press; 2011: 293-296. DOI: 10.1017/ CBO9780511977558

9. Yee AH, Burns JD, Wijdicks EFM. Cerebral salt wasting: pathophysiology, diagnosis, and treatment. Neurosurg Clin $\mathrm{N}$ Am 2010; 21: 339-352. DOI: 10.1016/j.nec.2009.10.011

10. Filippatos T, Liamis G, Christopoulou F, Elisaf M. Ten common pitfalls in the evaluation of patients with hyponatremia. Eur $\mathrm{J}$ Intern Med 2016; 29: 22-25. DOI: 10.1016/j.ejim.2015.11.022

11. McDonald AA, Yowler CJ. Fluid and electrolyte disorders. In: Wilson WC, Grande CM, Hoyt DB, eds. Trauma Critical Care. Vol. 2. New York: Informa Healthcare USA Inc; 2007: 781-784

12. Tolunay O, Celik T, Celik U, Kömür M, Yagci-Kupeli B. Cerebral salt wasting in pediatric critical care; not just a neurosurgical disorder anymore. Neuro Endocrinol Lett 2015; 36: 578-582

13. Leonard J, Garrett RE, Salottolo K, Slone DS, Mains CW, Carrick $\mathrm{MM}$, et al. Cerebral salt wasting after traumatic brain injury: a review of the literature. Scand J Trauma Resusc Emerg Med 2015; 23: 98. DOI: 10.1186/s13049-015-0180-5

14. Chaudhary N, Pathak S, Gupta M, Agrawal N. Cerebral salt wasting syndrome following head injury in a child managed successfully with fludrocortisone. Case Rep Pediatr 2016; 2016 : 6937465. DOI: $10.115 / 2016 / 6937465$ 
15. Lohani S, Devkota U. Hyponatremia in patients with traumatic brain inuury: etiology, incidence, and severity correlation. World Neurosurg 2011; 76(3-4): 355-360. DOI: 10.1016/ j.wneu.2011.03.042

\section{Sindrom cerebral cu pierdere de sare la pacienții cu traumatisme craniene minore - două cazuri clinice}

\section{Rezumat}

Descriem cazurile a doi pacienți politraumatizați internați în terapia noastră intensivă care au dezvoltat pe parcursul internării sindrom cerebral de pierdere de sare (CSWS) caracterizat prin pierdere de sare pe cale urinară, hiponatremie şi hipovolemie. Hiponatremia întâlnită în cadrul sindromului de secreție inadecvată de hormon antidiuretic (SIADH) şi CSWS apare frecvent la pacientii cu traumatism cerebral sever, hemoragie subarahnoidiană, tumori cerebrale, infecții ale sistemului nervos central.

CSWS a fost o surpriză la cei doi pacienti cu traumatism craniocerebral minor. Excluderea altor cauze de hiponatremie (SIADH, insuficiență corticosuprarenaliană secundară, disfuncție tiroidiană) este necesară pentru stabilirea diagnosticului; tratamentul adecvat al CSWS, cu reînlocuirea pierderilor de sodiu şi apă, scade riscul de mortalitate şi morbiditate. În concluzie, CSWS trebuie să fie luat în considerare la pacienţii politraumatizați care au suferit traumatism cerebral minor şi prezintă hiponatremie.

Cuvinte cheie: sindrom cerebral de pierdere de sare, hiponatremie hipovolemică, traumatism cerebral 